\title{
DESIGN LANDSCAPE URBANISM PADA TAMAN HORTIKULTURA TROPIS WADUK PLUIT
}

\author{
Fransiska Lasriama ${ }^{1}$, Tatang H. Pangestu ${ }^{2)}$ \\ 1)Program Studi S1 Arsitektur, Fakultas Teknik, Universitas Tarumanagara, fransiska.lasriama0503@yahoo.com \\ 2) Program Studi S1 Arsitektur, Fakultas Teknik, Universitas Tarumanagara, tatang_pangestu@hotmail.com
}

\begin{abstract}
Abstrak
Tumbuhan adalah makhluk hidup, tumbuhan dapat mempengaruhi kehidupan makhluk hidup lainnya, sehingga dapat dikatakan tumbuhan dapat mempengaruhi suatu ekosistem. Hortikultura merupakan salah satu jenis tanaman yang sangat beragam di Indonesia, dan dapat tumbuh di daerah perkotaan seperti Jakarta. Ekologi tanaman hortikultura harus dipelajari untuk melengkapi design landskap urbanisme ruang terbuka hijau kota dan juga dapat dikonsumsi oleh masyarakat. Namun, pengetahuan masyarakat tentang tanaman hortikultura yang bisa dikonsumsi sangat kurang, terutama kebiasaan masyarakat kota yang lebih cenderung mengkonsumsi makanan cepat saji, dimana kebiasaan ini sebenarnya tidak baik untuk tubuh dan ekosistem. Oleh karena itu, diperlukan suatu wadah yang mampu menghidupkan dan mampu mengembangkan tanaman hortikultura yang menyatu dengan kondisi tapak eksisting. Sehingga, kehadiran wadah arsitektur untuk menanam tanaman hortikultura tidak merusak kondisi ekosistem yang sudah ada. Perpaduan antara ilmu ekologi, teknologi arsitektur, metode arsitektur, dan teknologi menanam tanaman hortikultura diharapkan dapat menciptakan wadah arsitektur untuk tanaman hortikultura berkembang baik dan dapat menarik minat masyarakat untuk mengenal beberapa jenis tanaman hortikultura. Sebab, pengetahuan dan kesehatan manusia pun sangat mempengaruhi kualitas suatu ekosistem. Hortikultura yang ditanam juga merupakan tanaman yang dapat tumbuh didaerah tropis, terutama daerah tapak terpilih, yaitu di Jakarta Utara. Dengan demikian, hortikultura tidak hanya memberikan edukasi kepada masyarakat, tetapi dapat tumbuh, dan mengisi ruang publik perkotaan, seperti taman. Sehingga, tercipta ekosistem baru yang bermanfaat bagi sesama makhluk hidup.
\end{abstract}

Kata Kunci : Ekologi ; Hortikultura; Landskap Urbanisme

\begin{abstract}
Plants are living things, plants can affect the lives of other living things, so it can be said that plants can affect an ecosystem. Horticulture is one of the most diverse types of plants in Indonesia, and can be grown in urban areas such as Jakarta. The ecology of horticultural plants must be studied to complement the urban landscape design of urban green open spaces and can also be consumed by the community. However, people's knowledge about horticultural plants that can be consumed is very lacking, especially the habits of urban people who tend to consume fast food, where this habit is actually not good for the body and the ecosystem. Therefore, we need a container that is able to revive and be able to develop horticultural plants that blend with the existing site conditions. Thus, the presence of an architectural container for growing horticultural crops does not damage the existing ecosystem conditions. The combination of ecological science, architectural technology, architectural methods, and technology for growing horticultural plants is expected to create an architectural container for horticultural plants to develop well and can attract people's interest to know several types of horticultural plants. Because knowledge and human health greatly affect the quality of an ecosystem. The horticulture that is planted is also a plant that can grow in the tropics, especially the selected site area, namely in North Jakarta. Thus, horticulture not only provides education to the public, but can grow, and fill urban public spaces, such as parks. Thus, a new ecosystem is created that is beneficial to fellow living things.
\end{abstract}

Keywords: Ecology; Horticulture; Urbanism Landscape 


\section{PENDAHULUAN}

\section{Latar Belakang}

Indonesia memiliki sekitar 264,2 juta jiwa (data: BPS) dan terdiri dari 34 provinsi. Ini memungkinkan Indonesia memiliki masyarakat yang mempunyai selera rasa yang berbeda beda terhadap suatu jenis makanan. Dikarenakan kegiatan makan adalah kebutuhan primer maka, setiap nilai komposisi dalam makanan harus diperhatikan. Yang dimana, nilai komposisi tersebut dapat mempengaruhi kesehatan tubuh kita. Bahkan, jika dilihat secara lebih luas, kesehatan manusia pun dapat mempengaruhi kualitas sebuah ekosistem. Maka dari itu, masyarakat harus diimbangi dengan pengetahuan mulai dari mana bahan itu didapatkan sampai dengan pengolahannya. Karena, memperbaiki jenis makanan dapat membantu mengurangi kerusakan ekosistem dan menjauhi masyarakat urban dari penyakit mematikan akibat makanan.

Buah dan sayur adalah salah satu jenis bahan makanan utama, menurut Kemenkes : WHO menganjurkan setiap orang mengonsumsi 400 gram sayuran dan buah per hari. Takaran tersebut terbagi atas 250 gram sayur dan 150 gram buah. 250 gram asupan sayur per hari adalah setara dengan mengonsumsi dua porsi atau 2 gelas sayur yang dimasak dan ditiriskan. Balita dan anak usia sekolah dianjurkan untuk mengonsumsi 300-400 gram buah sayur per hari.

Indonesia, memiliki banyak hasil tanaman hortikultura, tanaman tersebut tersebar di 514 kabupaten/ kota, 7230 kecamatan. Dan setiap daerah memiliki tanaman yang beraneka ragam. Pada tahun 2018 - 2020 penghasilan negara, salah satunya berasal dari kegiatan ekspor hortikultura.

Namun, dari peristiwa tersebut, pada tahun 2016, masyarakat Indonesia tercatat hanya memakan buah dan sayur sebanyak 173 gram perharinya. Ini membuktikan bahwa Indonesia kaya akan hortikultura, namun masyarakatnya tidak mau mengkonsumsinya dengan baik.

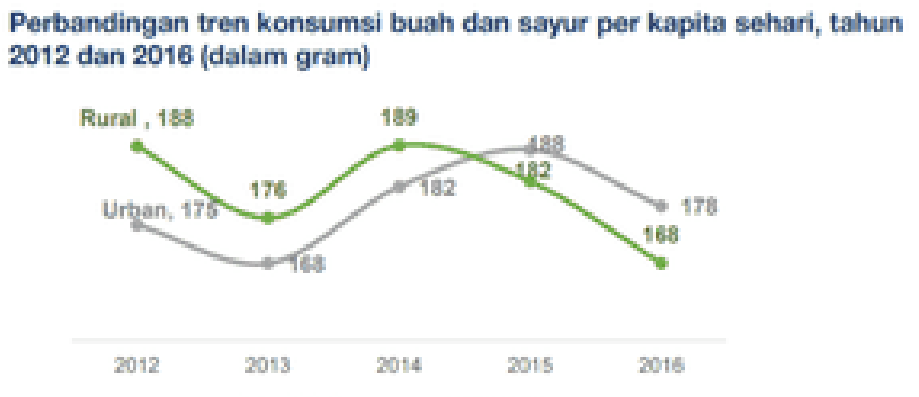

Gambar 1. Data BPS, Susenas Maret 2012 - 2016

Sumber : Power Point Buletin Pemantauan Ketahanan Pangan Indonesia

Sehingga, dibutuhkan sebuah pengenalan terhadap tanaman-tanaman hortikultura. Dikarenakan, tanaman hortikultura dapat membawa kesehatan bagi tubuh jika dikonsumsi dengan komposisi yang tepat dan baik untuk sebuah ekosistem. Namun, kurangnya sebuah sarana dan prasarana untuk pertumbuhan hortikultura harus diimbangi dengan adanya wadah atau perancangan tempat yang layak untuk menanam tanaman hortikultura, rancangan ini dibutuhkan demi mencapai sebuah kualitas tanaman yang baik. Karena nantinya tanaman hortikultura harus menarik perhatian masyarakat karena tanaman hortikultura akan dikonsumsi masyarakat dan juga akan hidup menciptakan ekosistem baru yang menyatu dengan makhluk hidup lainnya. 


\section{Rumusan Permasalahan}

a. Mengapa arsitektur dapat turut menciptakan wadah yang mendukung dan menampung kebutuhan tanaman hortikultura?

b. Kapan design arsitektur dapat menciptakan sebuah ekosistem yang baik dan mampu mencapai beyond ecology?

\section{Tujuan}

Tujuan penelitian ini, adalah menciptakan ekosistem yang mampu menghidupkan serta mengembangkan kegiatan aktivitas tumbuhnya tanaman hortikultura ditengah masyarakat kota.

\section{KAJIAN LITERATUR}

Ekologi adalah ilmu yang mempelajari hubungan atau keterkaitan antar makhluk hidup dan lingkungannya (Ernst Haeckel, 1866). Berikut ruang lingkup ekologi:

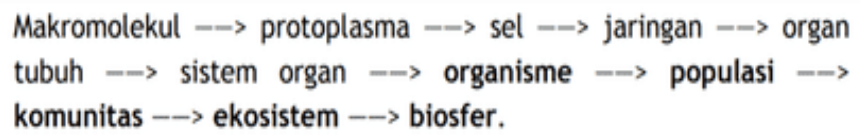

Gambar 2. Sistem Ruang Lingkup Ekologi

Sumber : Modul Pengertian Ruang Lingkup Ekologi dan Ekosistem

Salah satu jenis ekologi adalah tanaman, ada tanaman yang bisa dimakan dan ada juga yang tidak. Salah satu jenis makanan yang dapat dimakan adalah berasal dari tanaman hortikultura. Hortikultura adalah wujud dari mengembangkan sebuah tanaman buah, sayur, dan tanaman hias. (Janick,1972). Hortikultura pun memiliki beberapa manfaat seperti : memperbaiki gizi makanan, sebagai sumber lapangan kerja dan pendapatan negara, keindahan serta membentuk sebuah ekosistem. Namun, tanaman hortikultura pun memiliki beberapa kriteria yang harus diperhatikan, seperti : Waktu penyimpanan pendek, memerlukan tempat penyimpanan yang luas, mudah rusak saat dibawa, hampir bisa dikatakan melimpah karna banyak tanaman hortikultura dapat tumbuh disemua musim (sepanjang tahun), kenaikan harganya yang besar saat dijual (Notodimedjo, 1997).

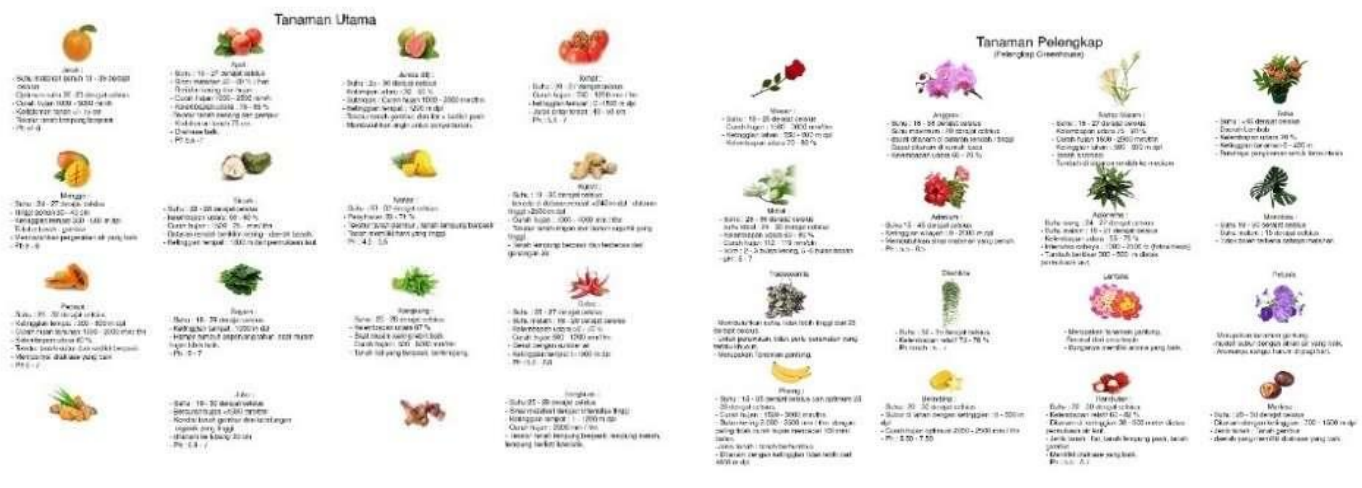

Gambar 3. Jenis Tanaman yang akan ditanam diwadah arsitektur Sumber : Analisis Pribadi

Karena tanaman hortikultura memiliki keberagaman jenis, tanaman ini bisa menciptakan sebuah pola dan membentuk susunan massa ditengah kota (Rustam Hakim,1987). Ruang publik memiliki 2 bentuk yaitu : ruang publik tertutup yaitu, ruang publik yang ada didalam bangunan, dan ruang publik terbuka yaitu area publik diluar bangunan (Car,2003). 


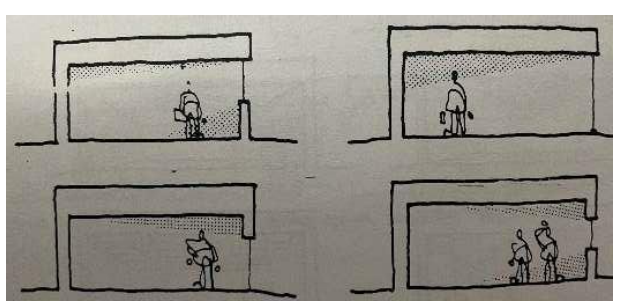

Gambar 4. Ruang Publik Tertutup Sumber : White, 1985

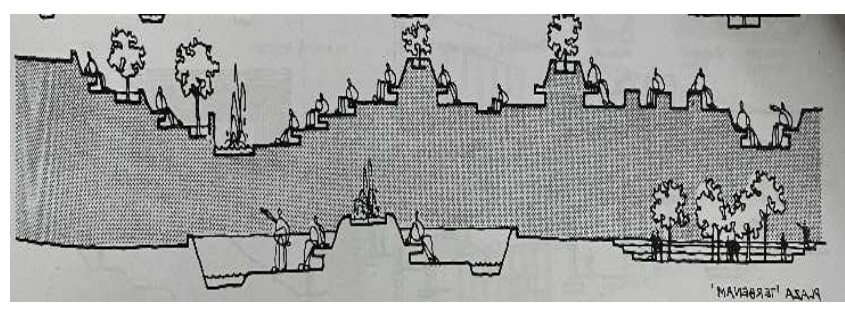

Gambar 5. Ruang Publik Terbuka

Sumber : White, 1985

Ruang publik pun memiliki beberapa point tertentu agar bisa dikatakan sebagai ruang publik yang baik bagi masyarakat, diantaranya memiliki sifat permeability (akses, dII), Variety (suasana/pengalaman ruang), Legibility (identitas sebuah tempat, sehingga masyarakat dapat mengenali ruang tesebut), dan robustness (tempat menampung aktivitas masyarakat) (lan Bentley). Salah satu bentuk ruang publik yang dapat menampung tumbuhan adalah taman. Taman adalah area yang dapat dibuat didalam/diluar bangunan, memiliki luasan dan mempengaruhi kondisi alam (suhu, iklim, dll) disuatu daerah (Sintia dan Murhananto, 2004). Taman memiliki beberapa kategori yaitu, taman umum yaitu taman yang diperuntukkan untuk publik, taman semi publik yaitu taman yang dapat digunakan bersama, dan taman pribadi, yaitu taman yang tidak diperuntukkan untuk publik.

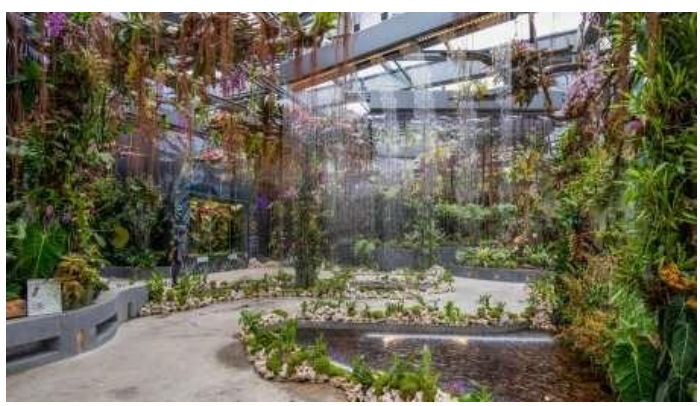

Gambar 6. Taman Publik Garden by The Bay Singapore Sumber : gardensbythebay.com.sg

Garden by The Bay Singapore adalah taman yang berada dipusat kota baru Singapura di Marina Bay. Taman ini merupakan salah satu taman yang menerapkan gabungan dari alam, teknologi, dan lingkungan.

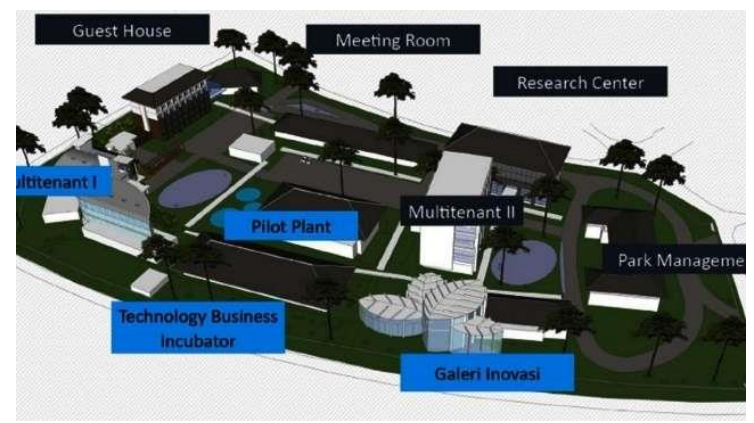

Gambar 7. Taman Semi Publik Science Techno Park Bogor Sumber : http://haipb.ipb.ac.id/

Area terpadu yang digunakan untuk pengembangan dan komersialisasi hasil inovasi produk dan jasa bidang pertanian tropis, pangan dan bio-sains yang didukung oleh fasilitas dan infrastrukur. 


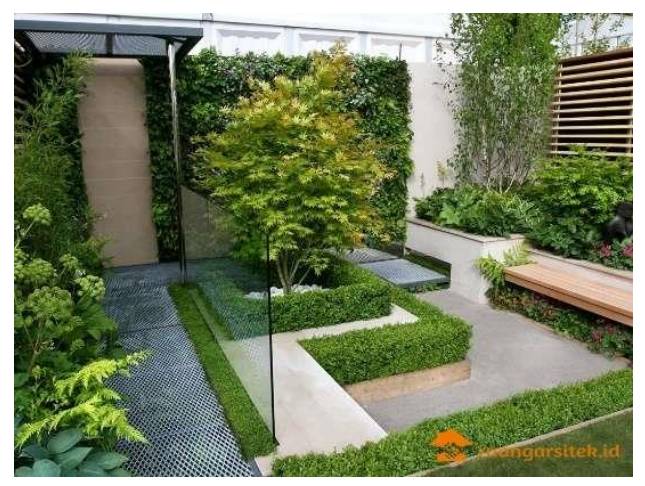

Gambar 8. Taman Pribadi

Sumber : ruangarsitek.id

Salah satu contoh taman pribadi adalah taman kecil yang dibuat di rumah kita sendiri. Taman juga dapat dibedakan dari luasannya meskipun fungsi secara keseluruhannya hampir sama. Taman berdasarkan luasannya dibedakan menjadi taman kota, taman lingkungan, dan taman ketetanggaan. Secara keseluruhan, taman memiliki fungsi yang sama yaitu :

a. Fungsi Ekologis, yaitu merupakan fungsi yang sangat utama, yaitu sebagai paru - paru kota, mengatur iklim, taman sebagai area serapan air.

b. Fungsi Sosial, yaitu merupakan fungsi yang lebih mengarah kepada masyarakat yaitu, sebagai area untuk membangun sebuah penelitian, objek Pendidikan.

c. Fungsi Ekonomi, yaitu menjadikan area tanam yang nantinya hasil tanam bisa diperjual belikan, serta bisa sebagai objek wisata dan pendidikan yang berbayar.

d. Fungsi Estetika, yaitu fungsi yang lebih mengarah ke indra penglihatan, yaitu keindahan, sebagai pemandangan untuk melembutkan kesan kaku dari bangunan kota (Cunawan, 2005).

Landskap adalah, sesuatu yang ada dibumi baik bersifat alami maupun buatan manusia yang masih merupakan bagian dari lingkungan dan dapat dipandang oleh mata manusia. Vegetasi tropis adalah, vegetasi yang berada di tropis lintang dan hidup di iklim yang hangat. Perancangan akan diarahkan dengan metode landscape urbanism, dengan pendekatan teori sebagai berikut :

\section{Spatial Type}

Spatial type terdiri dari : Merupakan sebuah bentuk aktivitas pengamatan. Gubahan awal adalah hasil bentukan dari landscaping eksisting yang ada, demi mencapai sebuah kontinuitas tapak, dan konsep perancangan berupa "Flowing Gardens".

- Pengamatan bentuk tapak

- Transformasi Massa

- Transformasi Gubahan Awal

- Transformasi gubahan mengikuti landscaping

\section{Spatial Depth}

- Perspektif/3d dari gubahan terhadap tapak

- Horizontal line background seperti : Langit, bangunan sekitar, dan sumber daya yang ada seperti air.

- Middle ground seperti hal - hal yang masih berada disekitar tapak dan memberi dampak untuk tapak.

- Foreground seperti : air, tanah, dll. 


\section{Spatial Enclosure}

- Zoning pencapaian seperti : zoning pejalan kaki, sepeda, mobil dan motor.

- Zoning dalam bangunan seperti penempatan fungsi - fungsi dan penentuan program ruang

- Zoning luar bangunan seperti fungsi - fungsi dan program ruang pendukung aktivitas bangunan bagian dalam.

Selain itu, konteks landspace urbanism juga membahas suasana kota yang kompleks, seperti : menangani infrastruktur, pengelolaan air, keanekaragaman hayati, aktivitas manusia, meneliti implikasi kota dalam lanskap dan lanskap di kota. (Christopher Gray:2011, dan Irfan Adi Permana, Indung Sitti Fatimah:2017).

\section{METODE}

\section{Metode Pengumpulan Data}

Data yang diperoleh merupakan data kualitatif dan kuantitatif, yang didapat dari hasil studi pustaka dan beberapa studi literatur. Studi pustaka dan literatur didapatkan dari jurnal, buku, video - video dari beberapa platform, dan beberapa website data pemerintah Indonesia khususnya kota Jakarta. Data tersebut, adalah data yang berkaitan dengan landscape urbanism (Makro) sampai dengan landscape urbanism (Mikro). Makro, artinya cakupan yang luas, seperti mempelajari keadaan landscape urbanism dari negara lain, serta mikro adalah mempelajari keadaan Negara Indonesia, khususnya Jakarta.

\section{Metode Desain}

Metode yang digunakan adalah metode landscape urbanism, dengan konsep flowing gardens yang berarti membuat taman indoor dan outdoor dan terkesan menyatu dengan keadaan tapak. Menyatu dan mengalir dibuat dengan tujuan untuk menjaga kontinuitas taman eksisting Waduk Pluit (sisi selatan dan utara Waduk Pluit) dan taman yang akan dirancang disekitar Waduk Pluit. Sehingga, terjadilah sebuah rancangan ruang terbuka hijau kota. Elemen yang digunakan adalah elemen landskap alami dan buatan. Sehingga terciptanya keselarasan ekosistem, baik dari segi fungsional maupun dari segi estetis dan kenyamanan untuk beraktivitas.

\section{DISKUSI DAN HASIL}

Dari diskusi, ditemukan beberapa hasil, mulai dari lokasi tapak, besaran/luas area tapak, program ruang, luasan program ruang, hingga teknisi bangunan yang akan digunakan.

1. Tapak

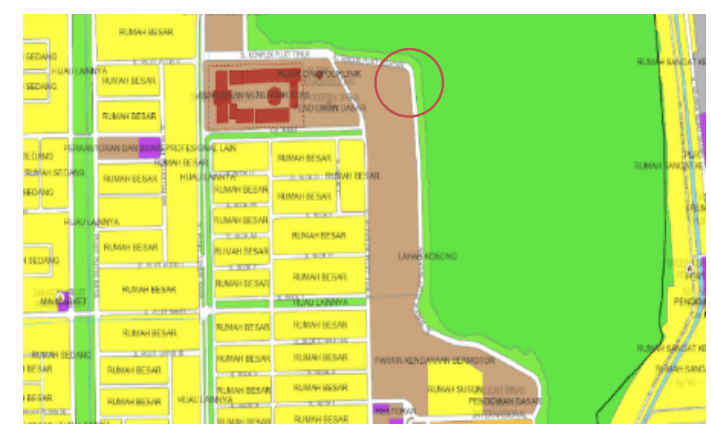

Gambar 9. Peta Perencanaan Kota Tapak di Waduk Pluit Sumber Gambar : jakartasatu.jakarta.go.id/ 


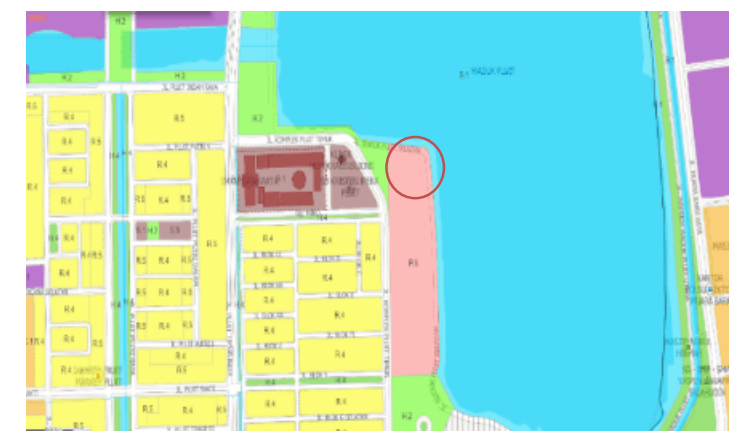

Gambar 10. Peta Perencanaan Kota Tapak di Waduk Pluit Sumber : jakartasatu.jakarta.go.id/

Tapak berada dikawasan Jakarta Utara, letaknya berada dikawasan Pluit, Jakarta Utara dengan lokasi depan Waduk Pluit. Memiliki luasan area total : $76.000 \mathrm{~m}^{2}$, luasan area lahan : 18.000 $\mathrm{m}^{2}$, luas bangunan : $6.000 \mathrm{~m}^{2}$ dengan kriteria KDB: 40, KLB: $0.8, \mathrm{~KB}: 2, \mathrm{KDH}: 20$. Dengan peruntukkan, memungkinkan dibangun area untuk tanaman hortikultura.

2. Program Ruang

Program ruang yang ditawarkan adalah, program ruang yang berhubungan dengan tanaman. Baik berupa area percontohan tanaman, laboratorium, café, dan supermarket serta didukung oleh utilitas / service bangunan.

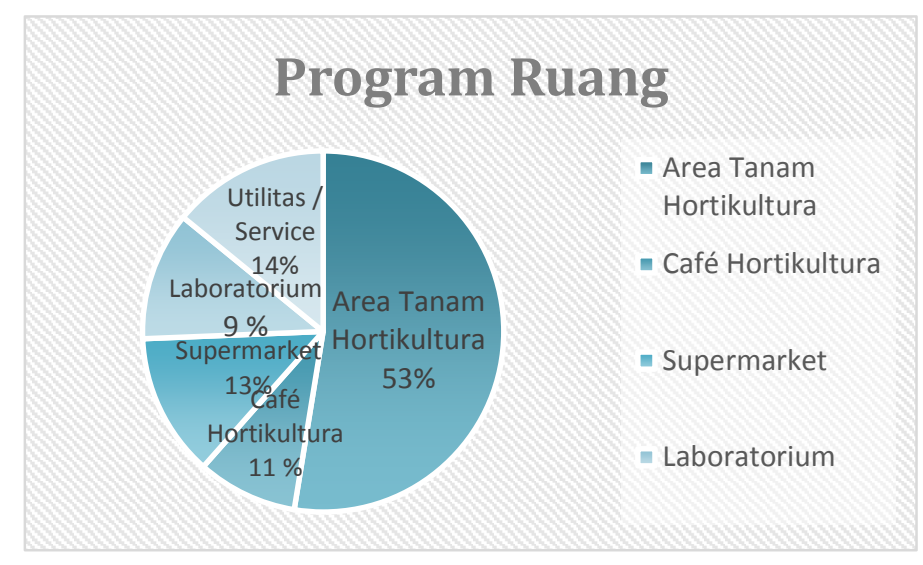

Gambar 11. Persenan Program secara Keseluruhan Sumber : Penulis, 2021

Dari data diatas, dapat dilihat bahwa rancangan arsitektur ini diperuntukkan untuk tanaman.

Tabel 1. Luasan Program Ruang

\begin{tabular}{cll}
\hline No. & \multicolumn{1}{c}{ Program Ruang } & Ukuran \\
\hline 1. & Hortikultura & $1950 \mathrm{~m}^{2}$ \\
\hline 2. & Café Hortikultura & $340 \mathrm{~m}^{2}$ \\
\hline 3. & Supermarket + Gudang & $712 \mathrm{~m}^{2}$ \\
\hline 4. & Laboratorium & $330 \mathrm{~m}^{2}$ \\
\hline 5. & Utilitas / Service & $730 \mathrm{~m}^{2}$ \\
\hline
\end{tabular}

Sumber : Analisis Pribadi 
3. Gubahan Massa

- Pengamatan bentuk dan keadaan tapak

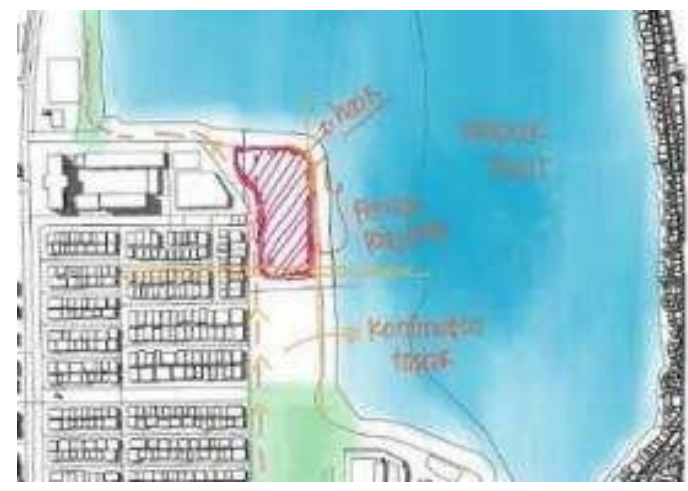

Gambar 12. Bentuk awal dasar tapak

Sumber : Penulis, 2021

Untuk menciptakan sebuah kontinuitas, bangunan sangat memperhatikan bentuk dan keadaan tapak yang sudah ada. Bentuk tapak nantinya akan mempengaruhi bentuk bangunan. Bentuk bangunan harus ramah terhadap lingkungannya. Sementara keadaan tapak, adalah keadaan ketinggian tapak (kontur), lingkungan sekitar tapak baik dari ketinggian bangunan, maupun fungsi bangunan sekitar. Karena, diharapkan bangunan yang akan dirancang akan menjadi ruang publik kota yang menguntungkan baik bagi lingkungan tapak maupun lingkungan sekitar.

- Transformasi Massa

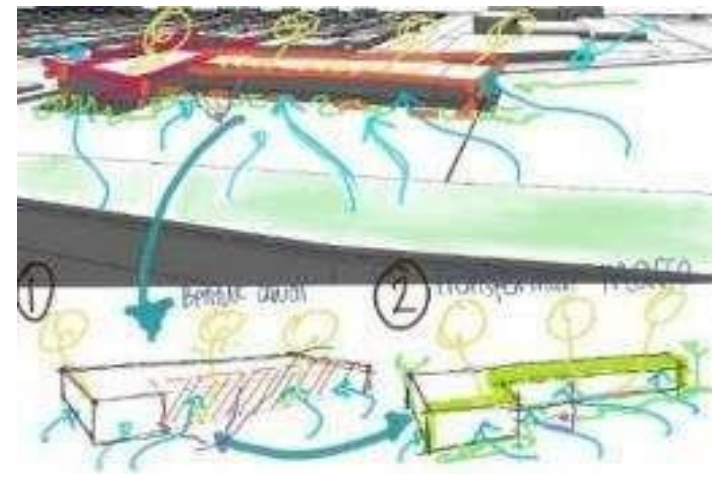

Gambar 13. Bentuk transformasi dasar Sumber : Penulis, 2021

Tranformasi massa berasal dari massa padat yang mengikuti bentuk tapak. Panjang dan padat, serta ketinggiannya tidak melebihi ketinggian bangunan sekitar tapak.

- Transformasi Gubahan Awal

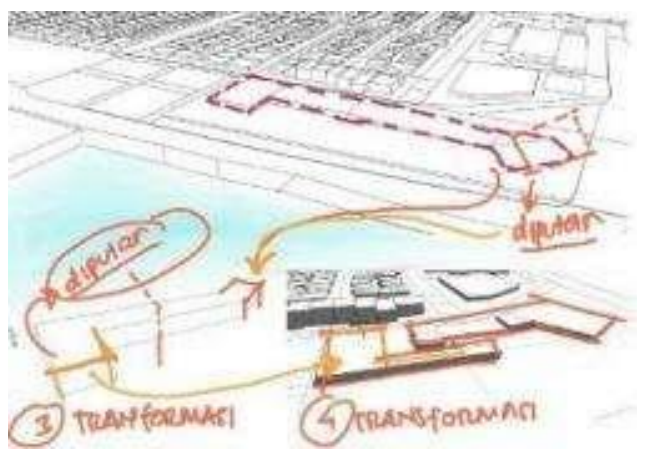

Gambar 14. Bentuk transformai gubahan Sumber : Penulis, 2021 
Kemudian, bentuk bangunan di split bentuk yang lebih nyata dengan bentuk hook, sehingga menimbulkan sudut pandang, sirkulasi matahari, udara yang baik terhadap bangunan dan tapak.

- Transformasi gubahan mengikuti landscaping

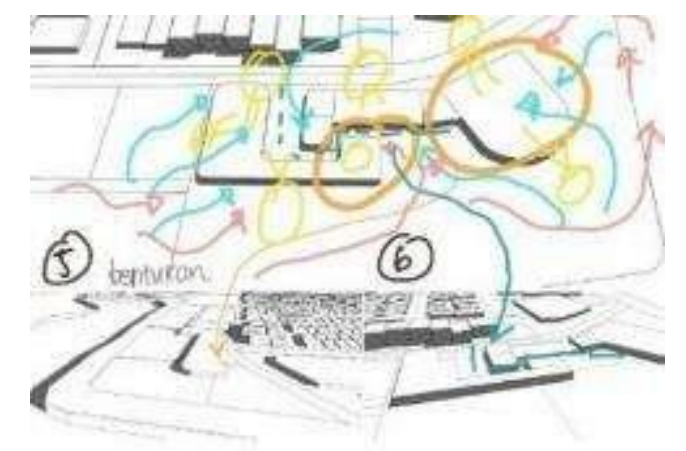

Gambar 15. Bentuk transformai akibat bentukan landscaping Sumber : Penulis, 2021

Bentuk yang sesuai diharapkan dapat membawa manfaat bagi bangunan itu sendiri dan bagi alam sekitarnya, terutama area tapak perancangan. Selain bentuk bangunan yang diperhatikan, sistem didalam dan diluar bangunan pun diperhatikan. Mulai dari cara menanam sampai sumber energi untuk bangunan.

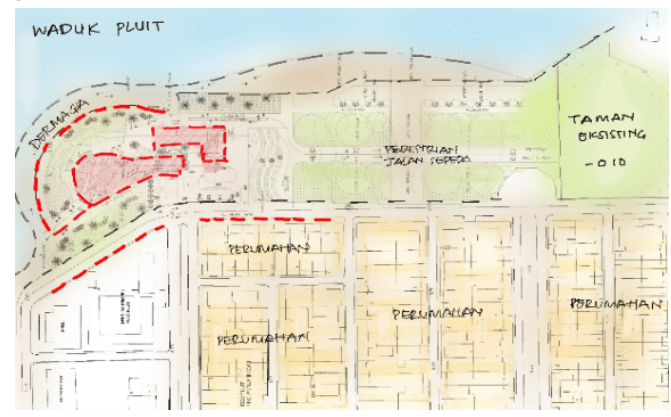

Gambar 16. Analisis bentuk berdasarkan bentuk tapak Sumber : Penulis, 2021

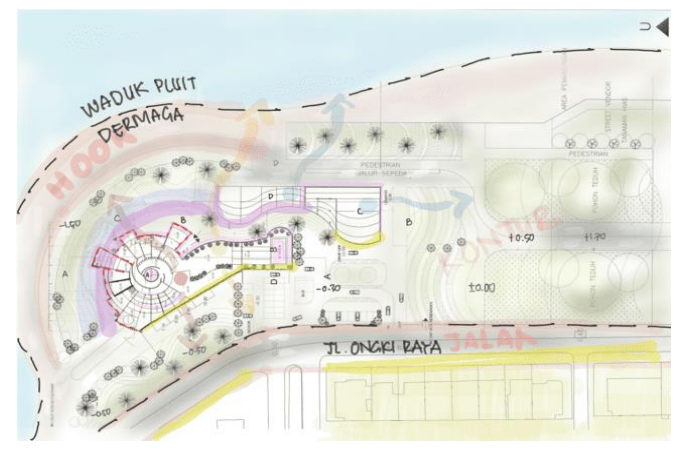

Gambar 17. Analisis bentuk berdasarkan sekitar tapak Sumber : Penulis, 2021

Dari bentuk massa, area yang menjorok kearea Waduk Pluit lebih bersifat dominan karena fungsinya sebagai daya tarik bangunan dan focal point dari bangunan. Sementara itu, sisi bangunan yang dekat dengan sisi jalan, lebih bersifat monoton mengikuti aksis dari bangunan perumahan sekitarnya. Memperhatikan adanya air sebagai sarana untuk sirkulasi udara dan matahari yang baik, sehingga area focal point mempunyai bentuk tidak monoton dan di design 
menggunakan material yang dapat menyerap panas dan bukaan untuk merespon sirkulasi udara. Design ini dapat merespon spatial depth sebagai indikator kedua dari landscape urbanism.

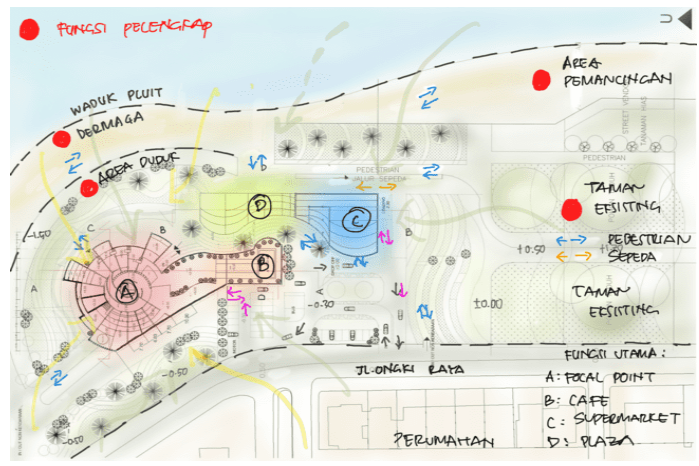

Gambar 18. Analisis Zoning

Sumber : Penulis, 2021

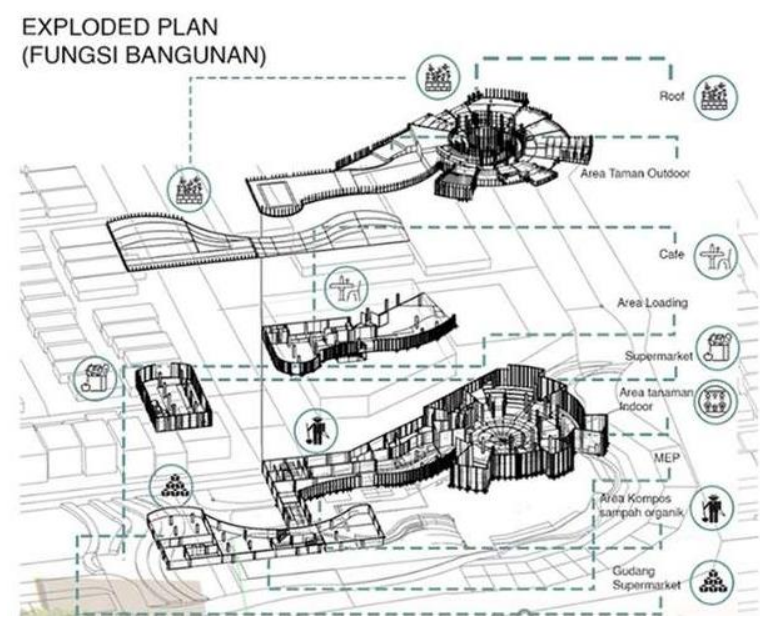

Gambar 19. Zoning Bangunan

Sumber : Penulis, 2021

Bagi pejalan kaki, pengguna sepeda, kendaraan pribadi, kendaraan service dan pemadam kebakaran sudah memiliki jalurnya masing - masing. Kemudian, bangunan utama terdiri dari dua massa.

- Bagian A adalah focal point sebagai zoning untuk menanam tanaman indoor. Dan bagian $B$ adalah café untuk merasakan makanan dengan bahan dasar tanaman hortikultura.

- $\quad$ Bagian C adalah area supermarket yang akan menjual beberapa persen hasil dari tanaman hortikultura yang sudah ditanam di area rancangan, serta tanaman yang berasal dari luar area rancangan dan bagian $D$ adalah area plaza terbuka dan berkontur, dimana masyarakat dapat duduk dan menikmati view kearah Waduk Pluit.

Ketika rancangan dan program untuk rancangan sudah tersedia, rancangan harus memiliki sistem teknisi. Sistem teknisi dimulai dari cara menanam sampai dengan sistem bangunan. Sistem teknisi menanam ada dua acara, yaitu penggunaan soil block dan penanaman di area rooftop bagi tanaman outoor. 
1. Soil Block adalah cara menanam dengan menggunakan biji - bijian.

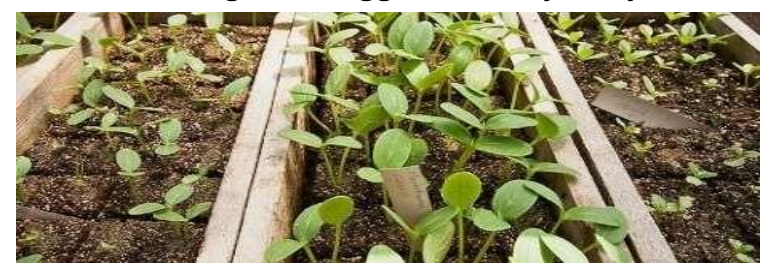

Gambar 20. Soil Block

Sumber : www.westcoastseeds.com

Sistem penanaman yang digunakan adalah menggunakan sistem soil block. Soil block adalah sistem penanaman ramah lingkungan karna tidak memerlukan lagi wadah berbahan plastik (seperti : pot). Cara menanamnya menggunakan wadah yang dicetak menjadi beberapa blok berbahan tanah dan pupuk, kemudian biji diletakkan diarea tanah dan pupuk. Penyiraman, dilakukan dalam periode tertentu dengan menggunakan air hangat - air suhu normal.

\section{Rooftop Garden}

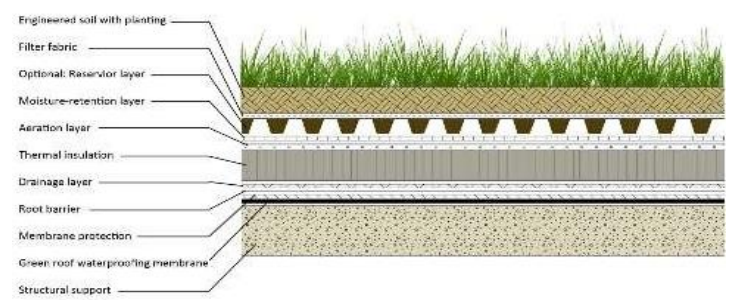

Gambar 21. Rooftop Garden

Sumber : Architizer.com

Sistem atap yang digunakan selain menggunakan kaca sebagai respon terhadap sumber cahaya matahari, adalah menggunakan atap beton yang nantinya akan ditanami tanaman. Berdasarkan urutan lapisan atap rooftop garden (dari atas ke lapisan terbawah) adalah tanaman, pupuk dan tanah, penyaring/filter, area aliran pembuangan air, waterproof, isolasi thermal, control uap, dan beton itu sendiri sebagai lapisan atap.

3. Rainwater Harvesting Tank

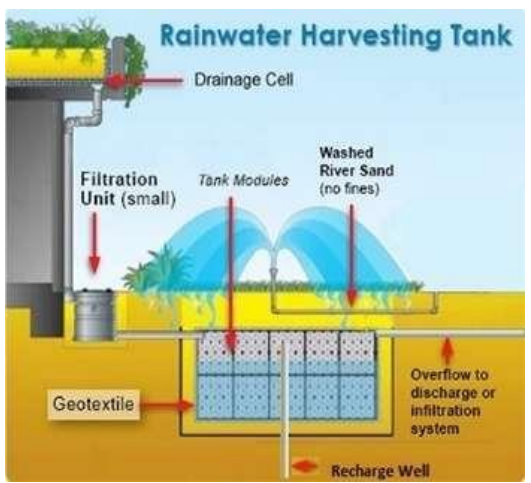

Gambar 22. Sistem air hujan Sumber : Indiamart.com

Sistem air hujan dapat berjalan dengan membutuhkan pipa drainase kemudian adanya filter air hujan, kemudian adanya pipa untuk menuju ke bak penyimpanan, kemudian adannya pump untuk mendorong air ke lantai bangunan yang akan menggunakan sumber air tersebut. 
4. Sistem air dari Waduk Pluit

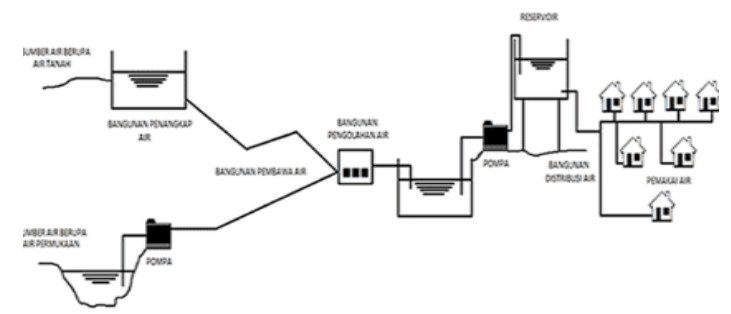

Gambar 23. Sistem air dari Waduk Pluit

Sumber : https://ensiklopedialingkungan.blogspot.com

Sistem air Waduk Pluit adalah sistem pengambilan air dari Waduk Pluit, kemudian air tesebut dipompa dan dibawa ke area pengolahan air untuk difiltrasi, dan kemudian air tersebut dipompa lagi menuju reservoir, dan kemudian disebarkan ke bangunan yang akan menggunakan sumber air tesebut.

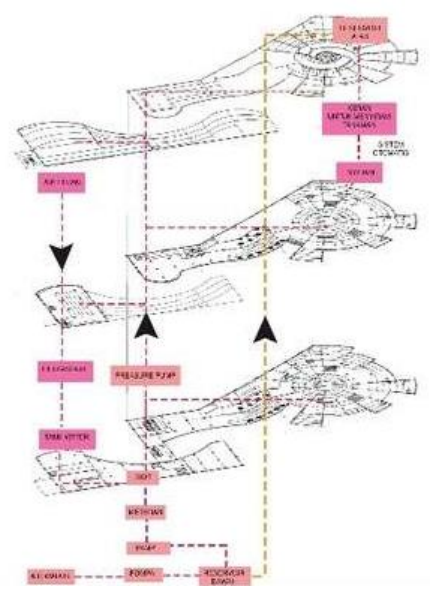

Gambar 24. Sistem Plumbing (air bersih)

Sumber : Analisis Pribadi

Air yang digunakan untuk bangunan adalah air yang berasal dari air Waduk Pluit dan air hujan. Kemudian disimpan di reservoir bawah. Dari reservoir bawah akan memompa ke reservoir atas. Air yang berada di reservoir atas diperuntukkan untuk menyiram tanaman yang nantinya akan disambung ke timer. Sehingga, tanaman akan tersiram secara otomatis.

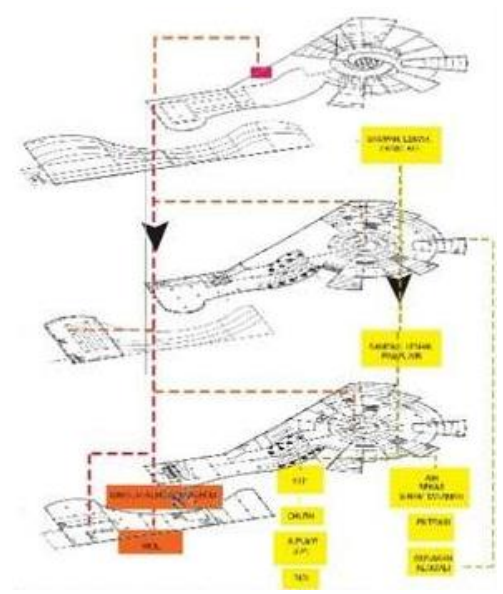

Gambar 25. Sistem Plumbing air kotor dan air kotoran Sumber : Analisis Pribadi 
Sementara, untuk plumbing kotoran merupakan hasil dari kotoran toilet, dan air kotor adalah air yang mengandung sampah, lemak, pasir, dan air bekas penyiraman tanaman. Namun, untuk air bekas penyiraman tanaman nantinya akan di filtrasi dan dapat digunakan kembali untuk penyiraman tanaman. Untuk air kotor lainnya dan kotoran akan dibuang ke roil.

5. Sistem pengudaraan dan sistem elektrikal bangunan

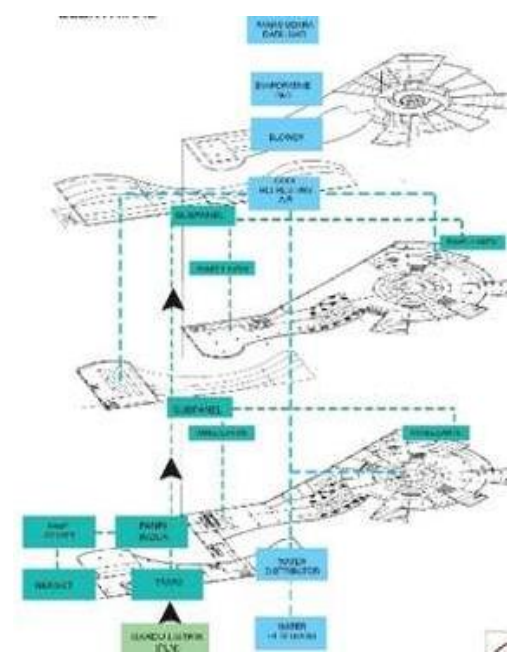

Gambar 26. Sistem Pengudaraan dan sistem elektrikal Sumber : Analisis Pribadi

Sistem bangunan juga harus diperhatikan seperti sistem pengudaraan dan sistem elektrikal bangunan. Sistem pengudaraan yang digunakan adalah sistem pengudaraan menggunakan evaporative pad dan sistem elektrikal yang digunakan adalah menggunakan sumber dari PLN dan genset.

6. Sistem kebakaran

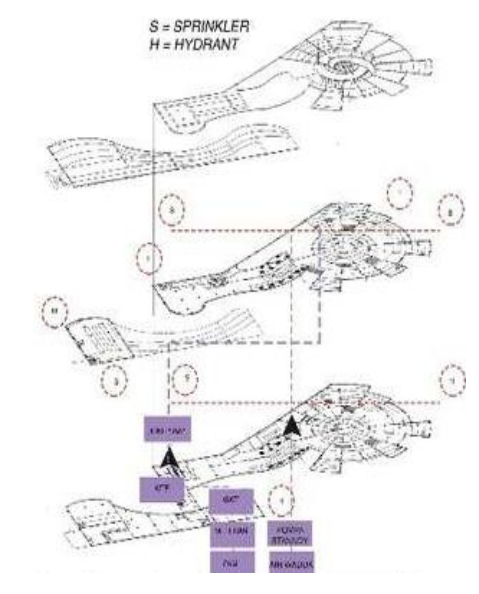

Gambar 27. Sistem Kebakaran

Sumber : Analisis Pribadi

Sistem kebakaran didukung dengan adanya sumber air dari Waduk Pluit. Kemudian air akan berkontribusi ke hydrant dan sprinkler saat terjadi api atau kebakaran.

Berdasarkan analisis, bahan bangunan yang akan digunakan adalah kaca, dinding $15 \mathrm{~cm}$, kisi kisi dengan bahan kayu. Kemudian, untuk mendukung sistem pengudaraan, digunakan sistem evaporative air. Dan untuk membantu sistem pengelolaan air, digunakan sistem pengelolaan air hujan dan air dari Waduk Pluit. 


\section{KESIMPULAN DAN SARAN}

\section{Kesimpulan}

Hortikultura merupakan salah satu kelompok tanaman yang ada di Indonesia. Namun, Indonesia belum mengolahnya dengan baik, mulai dari tempat/area menanam yang disediakan sampai dengan cara pengolahannya. Flowing gardens adalah konsep design sebuah wadah arsitektur, untuk menampung tanaman hortikultura sebagai subyek utama. Kemampuan ilmu ekologi, teknologi, dan arsitektur menyatukan dan menjaga kondisi tapak eksisting dan wadah yang dibuat di pinggir Waduk Pluit, konsep flowing gardens yang dibuat kontinuitas dengan taman eksisting Waduk Pluit. Design arsitektur dari peil, bentuk bangunan, bentuk olahan landscape, fungsi daerah sekitar, dan program yang ditawarkan diharapkan dapat menciptakan area hortikultura yang terus berkembang. Berkembang artinya, diharapkan design wadah yang sudah mengikuti kriteria tanaman, seperti suhu, permukaan tanah, jenis tanah, dan peredaran air yang dibantu dengan teknologi dapat menumbuhkan serta menambah jenis tanaman hortikultura di area tapak. Selain itu, wadah arsitektur yang dibentuk juga dapat menarik perhatian masyarakat serta menciptakan kegiatan-kegiatan baru disekitaran tapak.

Berdasarkan analisis yang sudah dilakukan, wadah yang diusulkan ini kiranya sudah dapat menjawab rumusan masalah yaitu menciptakan wadah dengan perpaduan ilmu ekologi, teknologi, dan arsitektur untuk tanaman dan wadah yang ingin mencapai beyond ecology. Karena konsep rancangan yang sangat menjaga kondisi tapak dan rancangan wadah arsitektur yang dibuat juga adalah rancangan yang mampu menampung makhluk hidup. Selain itu, rancangan arsitektur ini, dapat terus dikembangkan juga menjadi ruang terbuka hijau serta ruang publik kota yang menguntungkan bagi makhluk hidup dan ruang lingkup sekitar area rancangan tapak untuk keberlangsungan hidup seterusnya.

\section{Saran}

Tahap selanjutnya, diharapkan hasil rancangan ini dapat dikembangkan, sehingga jenis tanaman serta aktivitas masyarakat disekitaran tapak semakin beragam. Ketika jenis tanaman dan aktivitas masyarakat semakin beragam, artinya akan adanya perubahan - perubahan standard kriteria dalam bangunan. Dengan begitu, akan ada terciptanya sebuah ekosistem yang terus berkembang dan mampu menjaga baiknya sebuah lingkungan.

\section{REFERENSI}

Agusalim, V. (2015). Kebijakan dan Program Pembangunan Pertanian 2015-2019: Jakarta. Kementrian Pertanian.

Department of Agriculture and Food. (2014). The Holticulture Handbook. South Perth: Western Australian Agriculture Authority.South Perth: Western Australian Agriculture Authority.

Gandy, M.(2015).From Urban Ecology Urbanism: an Ambiguous Trajectory: London. Department of Geography University College London.

Garden by the Bay.Floral Fantasy. https://www.gardensbythebay.com.sg/en/things-todo/attractions/floral-fantasy.html

Gray, C.(2011). Landscape Urbanism: Definitions \& Trajectory. Scenario 01: Landscape Urbanism.

Info Alumni IPB. (2015). IPB Science Techno Park. http://haipb.ipb.ac.id/bisnis/ipb-sciencetechno-park

Ismaryati, E., Ari W., Nurtamtono H N.(2020). Panduan Teknis Penyusunan Prognosa Ketersediaan dan Kebutuhan Pangan Strategis. Badan Ketahanan Pangan: Jakarta Selatan. Kepala Sub Bidang Analisis Harga Pangan Konsumen dan Produsen.

Naess, A.(1989). Ecology, community and lifestyle. Australia. Press Syndicate of the University of Cambridge.

Permana, I A., Indung S F.(2017). Redesign Taman Kota Kabupaten Bogor dengan Pendekatan Urban Landscape Design: Bogor. Institut Pertanian Bogor. 
Prasetyo, B K. (2021). Taman Minimalis. https://ruangarsitek.id/taman-minimalis/

Pusparisa,Yosepha.(2020). Hidup Ditengah Pandemi, Dorong Perubahan Konsumsi Masyarakat :https://databoks.katadata.co.id/datapublish/2020/04/27/hidup-di-tengah-pandemidorong-perubahan-konsumsi-masyarakat\#.

Rianto, A D.(2016). Landasan Program Perencanaan dan Perancangan Arsitektur Pusat Perbelanjaan Bekonsep Citywalk di Kota Bogor: Semarang.

Rivai, dkk.(2016). Mengenal Sistem Hidrolika dalam Sistem Penyediaan Air Minum : https://ensiklopedialingkungan.blogspot.com/2016/08/mengenal-sistem-hidrolika-dalamsistem.html\#more.

Sepulveda J, dkk.(2010).Flavor Visualization: Taste Guidance in Co - Cooking System for Coexistance.

Subdirektorat Statistik Hortikkultura.(2019). Statistik Hortikultura 2019: Jakarta.BPS RI.

Suswono.(2013). Strategi Induk Pembangunan Pertanian 2013-2045:Jakarta. Kementrian Pertanian.

Sutanto, A.(2020). Peta Metode Desain: Jakarta.

The Food and Agriculture Organization of the United Nations and the World Trade Organization. (2017). Trade and Food Standards.

Unit Pengelola Statistik.(2021). Portal Statistik Sektoral Provinsi DKI Jakarta: https://statistik.jakarta.go.id/

Utoyo, S W., Sutriyono., Reda R.(2014). Pengertian Ruang Lingkup Ekologi dan Ekosistem: Banten. Universitas Tebuka.

Van Bergen Kolpha Architects.(2014). Architecture for Food: Netherlands. Architecture for Food Magazine.

Wfp.org.(2017). Buletin Pemantauan Ketahanan Pangan Indonesia Fokus Khusus: Tren Konsumsi dan Produk Buah dan Sayur: Indonesia. World Food Programme.

White, E. T.(1985). Buku Sumber Konsep: Bandung. Intermatra.

Winarni, I.(2008). Hortikultura. In: Ruang Lingkup dan Perkembangan Hortikultura: Jakarta. Universitas Terbuka.

Yeang, K., Lilian W.(2010). Dictionary of Ecodesign. New York: Routledge. 
